\title{
PENINGKATAN KEMAMPUAN MENULIS PARAGRAF ARGUMENTASI MELALUI METODE PEMBELAJARAN SCAFFOLDING METAKOGNISI SISWA KELAS X.1 MADRASAH ALIYAH NEGERI 1 MAKASSAR
}

\author{
Akbar Avicenna dan Muhammad. Akhir \\ Pendidikan bahasa dan Sastra Indonesia, Universitas Muhammadiyah Makassar \\ akbra.avicenna@unismuh.ac.id
}

\begin{abstract}
Abstrak
Berdasarkan hasil pengamatan yang dilakukan pada siswa Kelas X.1 Madrasah Aliyah Negeri 1 Makassar, diketahui bahwa kemampuan menulis paragraf argumentasi siswa di kelas tersbut masih tergolong rendah. Hasil observasi tersebut peneliti jadikan sebagai motivasi untuk melakukan penelitian. Jenis penelitian ini adalah penelitian tindakan kelas yang bertujuan untuk meningkatkan kemampuan menulis paragraf argumentasi melalui metode pembelajaran Scaffolding metakognisi siswa kelas X.1 Madrasah Aliyah Negeri 1 Makassar. Penelitian ini direncanakan pelaksanaannya sebanyak 2 siklus. Subjek penelitian ini adalah siswa kelas X.1 Madrasah Aliyah Negeri 1 Makassar tahun ajaran 2015/2016 sebanyak 36 siswa.Teknik pengumpulan data dengan menggunakan data kuantitatif dan data kualitatif. Data kuantitatif berupa hasil belajar siswa sedangkan data kualitatif berupa hasil pengamatan aktivitas belajar siswa. Penerapan, metode pembelajaran Scafoollding Metakognisi dapat meningkatkan kemampuan menulis paragraf argumentasi pada aspek "menulis topik,menyusun keramgka, mengembangkan kerangka, menyunting paragraf'.Hal ini ditunjukkan dari hasil nilai rata-rata keseluruhan dan nilai tes akhir yang mengalami peningkatan. Hal ini tampak dari pencapaian rata-rata hasil tes siklus I 22,2 meningkat menjadi 74,3 pada siklus ke II

Kata kunci : Keterampilan Menulis Paragraf Argumentasi Scaffolding Metakognisi
\end{abstract}

Abstract
Based on observations conducted on students of class X.1 Madrasah Aliyah Negeri 1
Makassar, it is known that the ability to write a paragraph argumentation tersbut
students in the class is still relatively low. The results of these observations the
researchers make it as motivation to do research. This research is a classroom action
research that aims to improve the ability to write a paragraph argumentation through
learning methods class X.1 Scaffolding students' metacognition Madrasah Aliyah Negeri
1 Makassar. The study was planned execution as much as 2 cycles. The subjects were
students of class X.1 Madrasah Aliyah Negeri 1 Makassar $2015 / 2016$ school year as
many as 36 students. Data collection techniques by using quantitative data and
qualitative data. The quantitative data in the form of student learning outcomes while
qualitative data in the form of observations of student learning activities. Implementation,
Scafoollding Metacognition learning methods to improve the ability to write a paragraph
argument on the aspect of "writing topics, preparing keramgka, develop a framework,
edit the paragraph" It is shown from the results of the overall average value and the
value of the final test is increased.This is evident from the average achievement test
results of the first cycle of 22.2 rose to 74.3 in cycle II Keywords: Writing Skills Metacognition Scaffolding paragraph Arguments 


\section{PENDAHULUAN}

Pendekatan konstruktivistik dalam pengajaran adalah salah satu upaya agar dalam pembelajaran bahasa Indonesia, siswa sendiri yang mengkonstruksi pengetahuan yang dipelajari. Piaget merupakan salah satu tokoh konstruktivistik, berpendapat bahwa anak membangun sendiri pengetahuannya dari pengalamannya sendiri dengan lingkungan. Dalam pandangan Piaget, pengetahuan datang dari tindakan, perkembangan kognitif sebagian besar bergantung kepada seberapa jauh anak aktif memanipulasi dan aktif berinteraksi dengan lingkungannya. Dalam hal ini peran guru adalah sebagai fasilitator dan buku sebagai pemberi informasi.

Karena pendekatan konstruktivistik dalam pengajaran bahasa Indonesia lebih menekankan pengajaran top-down daripada bottom-up, maka siswa sering mengalami hambatan dan berada pada daerah perkembangan terdekat atau ZPD

(Zone of proximal Development). ZPD siswa terjadi bisa diakibatkan karena belum cukup informasi pengetahuan awal siswa atau karena ketidakmampuan siswa mengorganisasi informasi/pengetahuan awalnya.

Untuk melaksanakan pembelajaran yang melibatkan scaffolding metakognisi, diperlukan perangkat yang sesuai. Pembelajaran bahasa Indonesia yang melibatkan scaffolding metakognisi masih relatif baru bahkan jarang terdapat di Indonesia sehingga perangkat pembelajaran yang mendukung pelaksanaannya di kelas masih sangat terbatas.

Setelah melakukan wawancara dan observasi tanggal 27 Agustus 2014 pada kelas $\mathrm{X}_{1}$ Madrasah Aliyah Negeri 1 Makassar ternyata ditemukan masih banyak siswa yang nilainya belum memenuhi syarat ketuntasan maksimum (KKM) pada mata pelajaran Bahasa
Indonesia yaitu 70. Dari 36 siswa, hanya 11 orang siswa saja yang memenuhi syarat ketuntasan maksimum (KKM) yang lainnya di bawah dari nilai ketuntasan maksimum. Hal in berarti ada $67,65 \%$ siswa pada kelas $\mathrm{X}_{1}$

Madrasah Aliyah Negeri 1

Makassar yang belum mencapai syarat ketuntasan maksimun dan hanya $32,35 \%$ siswa yang mencapai syarat ketuntasan maksimum. Dari data ini dapat disimpulkan bahwa pada $\mathrm{X}_{1}$ Madrasah Aliyah Negeri 1 Makassar terdapat masalah pada pelajaran Bahasa Indonesia khususnya dalam menulis paragraf argummentasi.

\section{TELAAH PUSTAKA}

\section{Menulis}

Hakikat menulis menurut S. Takala (dalam Munirah, 2007: 1) yaitu menulis atau mengarang adalah suatu proses menyusun, mencatat, dan mengkomunikasikan makna ganda, bersifat interaktif, dan diarahkan untuk mencapai tujuan tertentu dengan menggunakan suatu sistem tanda konvensional yang dapat dilihat (dibaca).

Bahasa tulis sangat diperlukan sebagai penyampaian isi pesan kepada orang lain dalam betuk tulisan. Oleh sebab itu, tulisan harus dapat dipahami oleh pembaca. Dengan demikian, penulis harus memiliki pula pengetahuan dan keterampilan dalam menggunakan bahasa tulis. Agar tulisan tersebut dapat

dipahami pembaca, penulis juga harus menguasai bahasa pembaca sebagaimana yang diharapkan.

Hal itu menunjukkan bahwa menulis merupakan kegiatan yang sangat rumit dan kompleks. Oleh sebab itu, penulis hendaknya mengungkapkan gagasannya dengan jelas. Dengan kata lain, dia harus menggunakan bahasa dengan tepat, dan 
siapa pembaca yang dituju. Di samping itu, penulis harus memiliki keterampilan memilih dan menata gagasan sehingga pesan yang disampaikan mudah dipahami oleh para pembaca. Hal itu diperlukan karena kegiatan menulis merupakan bentuk kegiatan komunikasi secara tidak langsung. Sebaliknya, dalam komunikasi tidak langsung digunakan bahasa yang benar-benar efektif agar mudah dipahami oleh orang lain.

Sejalan dengan pendapat tersebut, Syafi'ie (2001: 45) mengemukakan bahwa untuk menghasilkan tulisan yang baik, penulis harus memiliki kemampuan khusus ke arah itu. Dia terlebih dulu harus (a) mengetahui masalah yang akan ditulis, (b) memahami kondisi pembaca, (c) menyusun perencanaan penilaian, (d) menggunakan bahasa, (e) memulai tulisan, dan (f) memeriksa tulisan.

Tulisan akan menjadi efektif jika pertama-tama penulis memiliki objek yang akan dikemukakan. Bila objek telah ditentukan, penulis harus memikirkan dan utamanya secara jelas dan rinci serta memilih dan menggunakan bahasa secara cermat untuk diungkapkannya.

\section{Paragraf}

Paragraf adalah bagian-bagian gagasan yang dituangkan dalam sebuah tulisan. Paragraf juga dapat dikatakan sebagai sebuah karangan pendek atau mini. Para ahli bahasa merumuskan pengertian Paragraf itu dengan menggunakan teknik yang berbeda, meskipun pengertian yang dirumuskan tersebut bebrbeda tetap tidak akan mengurangi pemahaman tentang paragraph itu sendiri karena pengertian yang dirumuskan tidak jauh berbeda.

Istilah paragraf muncul sekitar tahun 1970-an di Indonesia. Para ahli bahasa umumnya berpendapat sama tentang wacana dalam hal satuan bahasa yang terlengkap (utuh) tetapi dalam hal lain ada perbedaannya. Perbedaannya terletak pada wacana sebagai unsur gramatikal tertinggi yang direalisasikan dalam bentuk paragraf yang utuh dengan amanat yang lengkap dan dengan koherensi serta kohesi tinggi.

Paragraf berisi sesuatu yang penulisan awalnya dimajukan beberapa ketukan atau spasi. Dari beberapa pengertian paragraph merupakan seperangkat kalimat yang berkaitan erat satu sama lain. Berdasarkan pandangan tersebut dapat didefinisikan paragraf sebagai seperangkat kalimat yang tersusun secara logis dan sistematis. Pada beberapa pengertian yang dikemukakan, maka dapat dipahami dan dijelaskan bahwa paragraph sebagai inti penuangan buah pikiran yang didukung oleh semua kalimat yang ada di dalamnya mulai dari kalimat pengenal, yaitu kalimat utama atau kalimat topik, kalimat penjelas sampai dengan penutur. Kumpulan kalimat tersebut saling bertalian dalam satu rangkaian yang berfungsi membentuk seperangakat kalimat yang tersusun secara logis dan gagasan sistematis di dalamnya yang mengungkap satu gagasan.

Argumentasi adalah lapangan yang bertujuan meyakinkan dan memengaruhi pembaca dengan alasan-alasan yang logis dan kuat guna membuktikan kebenaran suatu pendapat yang didasarkan atas data dan fakta. Argumentasi digunakan untuk memengaruhi dan mengubah pendapat orang lain agar menerimanya. Dalam penyusunan argumentasi semua hal yang dianggap penting dikelompokkan dan dijadikan satu dalam suatu kesimpulan yang bisa diletakkan di awal, akhir, atau di awal dan di akhir paragraf.

\section{Ciri-ciri Paragraf Argumentasi}

a. Menjelaskan pendapat agar pembaca yakin. 
Memerlukan fakta untuk pembuktian berupa gambar/grafik, dan lain-lain.

b. Menggali sumber ide dari pengamatan, pengalaman, dan penelitian.

c. Penutup berupa kesimpulan.

\section{Bentuk Karangan Argumentasi}
a. Artikel
b. Tajuk Rencana
c. Kritik atau Esai

\section{Model Pembelajaran Scaffolding Metakognisi}

Scaffolding merupakan suatu proses yang digunakan orang dewasa atau orang yang lebih memahami untuk menuntun anak-anak melalui daerah perkembangan terdekatnya (ZPD-nya). Istilah scaffolding ini ditemukan oleh seorang ahli psikologi perkembangan-kognitif masa kini, Jerome Bruner, yakni scaffolding merupakan jembatan pada daerah ZPD yang membantu siswa dalam menyelesaikan tugas.

Maksud dari ZPD adalah menitikberatkan pada interaksi sosial yang akan memudahkan perkembangan siswa. Ketika siswa mengerjakan pekerjaannya di sekolah sendiri, perkembangan mereka kemungkinan akan berjalan lambat. Untuk memaksimalkan perkembangan, siswa seharusnya bekerja dengan teman yang lebih terampil yang dapat memimpin secara sistematis dalam memecahkan masalah yang lebih kompleks. Melalui perubahan yang berturut-turut dalam berbicara dan bersikap, siswa mendiskusikan pengertian barunya dengan temannya kemudian mencocokkan dan mendalami kemudian menggunakannya.

Tugas dalam zona perkembangan terdekat adalah tugas yang tidak dapat dilakukan sendiri oleh anak, tetapi dia akan membutuhkan bantuan dari teman sebaya, orang dewasa atau orang yang lebih memahami. Tugas-tugas dalam zona ini belum dipelajari oleh seorang anak tetapi dapat dipelajari jika diberi waktu yang sesuai. Untuk melewati ZPD siswa, maka dibutuhkan scaffolding.

Dalam dunia pendidikan, istilah scaffolding merupakan pengembangan dari teori belajar konstruksivisme modern. Scaffolding pertama kali disebut sebagai istilah dalam dunia pendidikan oleh Vygotsky (1846). Dalam pembelajaran diketahui dan apa yang tidak diketahui. Sedang strategi metakognisi merujuk kepada cara untuk meningkatkan kesadaran mengenai proses berpikir dan pembelajaran yang berlaku sehingga bila kesadaran ini terwujud, maka seseorang dapat mengawal pikirannya dengan merancang, memantau dan menilai apa yang dipelajarinya.

Dari berbagai definisi metakognisi yang dikemukakan beberapa ahli pakar di atas, maka dirumuskan pengertian metakognisi yang digunakan dalam penelitian ini adalah kesadaran seorang siswa untuk mampu mengetahui potensi dirinyadan kemudian berusaha terampil dalam merencanakan, monitoring, dan mengevaluasi berbagai pengetahuan yang didapatkannya.

\section{METODE PENELITIAN}

\section{Jenis Penelitian}

Penelitian ini adalah penelitian tindakan kelas (scaffolding metakognisi) dengan tahapan-tahapan pelaksanaan meliputi perencanaan, pelaksanaan tindakan, evaluasi dan refleksi secara langsung yang selanjutnya tahapantahapan tersebut dirangkai dalam satu siklus kegiatan. 


\section{Lokasi dan Subjek Penelitian}

Penelitian ini akan dilaksanakan di Madrasah Aliyah Negeri 1 Makassar. Sebagai subjek penelitian adalah siswa kelas $\mathrm{X}_{.1}$ yang terdaftar pada tahun pelajaran 2013/2014 dengan jumlah siswa 36 orang yang terdiri 20 laki-laki dan 16 perempuan.

\section{Instrumen Penelitian}

Instrumen penelitian ini adalah bentuk tes dan observasi. Bentuk tes yang digunakan adalah tes tertulis. Instrumen penelitian ini merupakan komponen utama dalam rencana pelaksanaan pembelajaran (RPP). Format RPP yang digunakan dalam pembelajaran menulis paragraf argumentasi melalui metode scaffolding metakognisi mengikuti format yang sesuai standar sebagaimana pada lampiran.

\section{Teknik Pengumpulan Data}

Untuk memperoleh data dan informasi yang dibutuhkan maka teknik pengumpulan data yang digunakan dalam penelitian ini adalah:

\section{Tes}

Tes adalah alat pengukuran berupa pertanyaan, perintah, dan petunjuk yang ditujukan kepada siswa untuk mendapatkan respon sesuai petunjuk. Bentuk tes yang dipilih dalam penelitian ini adalah bentuk tertulis dan unjuk kerja 2. Observasi

Observasi digunakan untuk mengamati latar kelas tempat berlangsungnya pembelajaran menulis paragraf argumentasi. Teknik ini dilakukan dengan mengamati aktivitas belajar mengajar dan interaksi yang terjadi di dalam kelas selama kegiatan pembelajaran. Instrumen yang digunakan dalam kegiatan observasi adalah lembar observasi.

Data yang ingin diperoleh dari lembar observasi ini adalah komunikasi interaktif antara guru dan siswa secara langsung pada saat pembelajaran bahasa Indonesia menggunakan metode scaffolding metakognisi, motivasi belajar, dan keaktifan siswa dalam proses pembelajaran

\section{Teknik Analisis Data}

Data yang diperoleh akan dianalisis dengan menggunakan teknik analisis kuantitatif dan kualitatif. Analisis kuantitatif digunakan untuk menganalis data tentang hasil belajar siswa. Sedangkan analisis kualitatif digunakan untuk menganalisis data tentang hasil observasi, tanggapan siswa, perhatian, antusias dalam pembelajaran, motivasi belajar dan sejenisnya. Untuk analisis kuantitatif digunakan statistik deskriptif misalnya mencari rata-rata, persentase keberhasila belajar, tabel frekuensi, persentase nilai terendah dan tertinggi yang didapatkan siswa dengan menggunakan metode scaffolding metakognisi.

Adapun rumus yang digunakan untuk menentukan kualifikasi tingkat keberhasilan siswa dalam presentase adalah:

Jumlah skor yang diperoleh siswa x 100\% Banyaknya subjek

Pedoman yang digunakan untuk mengetahui tingkat kemampuan siswa dalam menulis paragraf argumentasi adalah sebagai berikut:

\begin{tabular}{ccc} 
Interval Tingkat Penguasaan & Kategori Nilai & Keterangan \\
\hline $85-100$ & $\mathrm{~A}$ & Baik Sekali \\
\hline
\end{tabular}




\begin{tabular}{ccc}
\hline $75-84$ & B & Baik \\
\hline $60-74$ & C & Cukup \\
\hline $40-59$ & D & Kurang \\
\hline $0-39$ & E & Kurang Sekali \\
\hline & & (Nurgiyantoro, 2001: 399)
\end{tabular}

\section{HASIL PENELITIAN DAN PEMBAHASAN}

\section{Hasil penelitian}

Siklus pertama terdiri dari empat tahapan yakni perencanaan, pelaksanaan, observasi dan refleksi.

Pembelajaran ini diikuti oleh 36 orang siswa. Pada siklus pertama, metode pembelajaran Scaffolding Metakognisi yang diterapkan belum sempurna. Hal tersebut berdampak pada kemampuan siswa melaksanakan kegiatan dan berakibat terhadap maksimalnya perubahan sikap siswa ini dapat dilihat sebagai berikut:

Tabel 4.1. Data Hasil Observasi Sikap Siswa Selama Mengikuti Pembelajaran Siklus I

\begin{tabular}{|c|c|c|c|c|c|c|c|}
\hline \multirow{2}{*}{ No } & \multirow{2}{*}{ Kemampuan Yang Diamati } & \multicolumn{4}{|c|}{$\underline{\text { Pertemuan }}$} & \multirow{2}{*}{$\begin{array}{l}\text { Rata- } \\
\text { rata }\end{array}$} & \multirow{2}{*}{$\begin{array}{c}\text { Persentase } \\
(\%)\end{array}$} \\
\hline & & I & II & III & IV & & \\
\hline 1 & $\begin{array}{lrrr}\text { Jumlah } & \text { siswa } & \text { yang } & \text { hadir } \\
\text { pada } & \text { saat } & & \text { kegiatan } \\
\text { pembelajaran } & & \\
\end{array}$ & 32 & 34 & 36 & 36 & 34,50 & 95,83 \\
\hline 2. & $\begin{array}{l}\text { Siswa yang memperhatikan } \\
\text { pada saat proses } \\
\text { pembelajaran }\end{array}$ & 25 & 28 & 30 & 34 & 29,26 & 81,27 \\
\hline 3 & $\begin{array}{l}\text { Siswa yang melakukan } \\
\text { aktifitas negative selama } \\
\text { proses pembelajaran (main- } \\
\text { main, ribut, dan lain-lain) }\end{array}$ & & 4 & 3 & 2 & 3,25 & 9,72 \\
\hline 4 & $\begin{array}{l}\text { Siswa yang aktif } \\
\text { pembelajaran }\end{array}$ & 20 & 28 & 30 & 34 & 28 & 79,68 \\
\hline 5 & $\begin{array}{l}\text { Siswa yang memahami } \\
\text { materi yang diajarkan }\end{array}$ & 20 & 28 & 29 & 18 & 23,7 & 77,78 \\
\hline 6 & $\begin{array}{l}\text { Siswa yang masih perlu } \\
\text { bimbingan guru pada saat } \\
\text { mengerjakan soal. }\end{array}$ & 5 & 8 & 6 & 3 & 5,5 & 15,27 \\
\hline 7 & $\begin{array}{lll}\text { Siswa yang kurang } \\
\text { memahami materi }\end{array}$ & 6 & 7 & 4 & 6 & 5,75 & 15,97 \\
\hline 8 & $\begin{array}{l}\text { Siswa yang bertanya } \\
\text { tentang materi yang belum } \\
\text { dimengerti }\end{array}$ & 6 & 3 & 3 & 6 & 45 & 12,5 \\
\hline
\end{tabular}


Pada tabel 4.1. diperoleh bahwa pada siklus I dari 36 siswa yang hadir pada saat kegiatan pembelajaran sebanyak $95,83 \%$,siswa yang memperhatikan pada saat proses pembelajaran sebanyak $81,27 \%$, siswa yang melakukan aktifitas negative selama proses pembelajaran (mainmain, rebut, dll) mencapai $9,72 \%$. Siswa yang aktif dalam pembelajaran $79,68 \%$, siswa yang memahami materi yang diajarkan $77,78 \%$, siswa yang membutuhkan bimbingan guru pada saat mengerjakan soal $15,27 \%$, siswa yang kurang memahami materi sebanyak $15,97 \%$, dan siswa yang bertanya tentang materi yang belum dimengerti sebanyak $16,12,56 \%$. Untuk data kemampuan menulis paragraf argumentasi siswa dapat dilihat pada tabel tes siklus I sebagai berikut:

\section{1) Penilaian Aspek Peningkatan, Menulis Topik, Menyusun Kerangka,Pengembangan Kerangka, dan Menyunting Paragraf Siklus I.}

Untuk soal peningkatan menulis paragraph argumentasi mengacu pada indikator mampu menulis topik, menyusun kerangka, mengembangkan kerangka, dan menyunting paragraf.

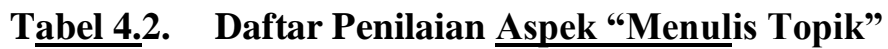

\begin{tabular}{|c|c|c|c|c|}
\hline No. & Kategori & Interval & $\begin{array}{l}\text { Frekuens } \\
\text { i }\end{array}$ & $\%$ \\
\hline \multicolumn{5}{|c|}{ Skor } \\
\hline 1. & Sangat baik & $12-15$ & 4 & 11,1 \\
\hline 2. & Baik & $8-11$ & 13 & 36,1 \\
\hline 3. & Cukup & $4-7$ & 18 & 50 \\
\hline 4. & Kurang & $0-3$ & 1 & 2,8 \\
\hline \multicolumn{2}{|c|}{ Jumlah } & & 36 & 100 \\
\hline \multicolumn{3}{|c|}{ Rata-rata } & \multicolumn{2}{|c|}{8,28} \\
\hline
\end{tabular}

Berdasarkan tabel 4.2. pada aspek menulis paragraf argumentasi " menulis topik " dari 36 siswa terdapat 4 siswa yang mencapai kategori sangat baik dengan interval skor 12-15, atau sebesar $11.1 \%$. Untuk kategori baik dengan interval skor 8-11 dicapai oleh 13 siswa atau sebesar $36,1 \%$. Untuk yang berkategori cukup dengan interval skor 4-7 dicapai oleh 18 siswa atau sebesar $50 \%$. Sedangkan untuk kategori kurang dengan interval 0-3 dicapai oleh 1 siswa atau $2,8 \%$.

Berdasarkan nilai rata-rata siswa yang diperoleh sebesar 8,28. Hasil tersebut termasuk dalam kategori cukup, artinya keterampilan siswa dalam penguasaan aspek "menulis topik" termasuk dalam kategori cukup. Pada aspek"menulis topik" dalam siklus I ini , masih banyak siswa yang belum dapat menuliskan topik secara saksama. Pada aspek ini sebagian besar siswa, banyak yang mendapat nilai berkategori cukup dengan interval skor 4-7. Ini berarti banyak siswa menulis topik tidak sesuai dengan paragraf. 
Tabel 4.3. Daftar Penilaian Aspek "Menvusun Kerangka"

\begin{tabular}{lllcc}
\hline No. & Kategori & Interval & Frekuensi & \% \\
\hline & & Skor & & \\
\hline 1. & Sangat baik & $12-15$ & 6 & 16,7 \\
\hline 2. & Baik & $8-11$ & 10 & 27,8 \\
\hline 3. & Cukup & $4-7$ & 19 & 52,8 \\
\hline 4. & Kurang & $0-3$ & 1 & 2,8 \\
\hline Jumlah & & & 36 & 100 \\
\hline Rata-rata & & & 8,50 \\
\hline
\end{tabular}

Berdasarkan tabel 4.3. pada aspek menulis paragraf argumentasi " menyusun kerangka " dari 36 siswa terdapat 6 siswa yang mencapai kategori sangat baik dengan interval skor 12-15, atau sebesar $16,7 \%$. Untuk kategori baik dengan interval skor 8-11 dicapai oleh 10 siswa atau sebesar $27,8 \%$. Untuk yang berkategori cukup dengan interval skor 4-7 dicapai oleh 19 siswa atau sebesar $52,8 \%$. Sedangkan untuk kategori kurang dengan interval 0-3 dicapai oleh 1 siswa atau $2,8 \%$.

Berdasarkan nilai rata-rata siswa yang diperoleh sebesar 8,50
Hasil tersebut termasuk dalam kategori cukup, artinya keterampilan siswa dalam penguasaan aspek "menyusun kerangka" termasuk dalam kategori cukup. Pada aspek "menyusun kerangka" dalam siklus I ini, masih banyak siswa yang belum dapat menyusun kerangka dengan lengkap. Pada aspek ini sebagian besar siswa, banyak yang mendapat nilai berkategori cukup dengan interval skor 4-7. Ini berarti banyak siswa menyusun kerangka tidak lengkap

Tabel 4.4. Daftar Penilaian Aspek "Mengembangkan Kerangka"

\begin{tabular}{lllcc}
\hline No. & Kategori & Interval & \multicolumn{2}{c}{ Frekuens } \\
i & \% \\
\hline & & Skor & & \\
\hline 1. & Sangat baik & $12-15$ & 4 & 11,1 \\
\hline 2. & Baik & $8-11$ & 14 & 38,9 \\
\hline 3. & Cukup & $4-7$ & 17 & 47,2 \\
\hline 4. & Kurang & $0-3$ & 1 & 2,8 \\
\hline Jumlah & & 36 & 100 \\
\hline Rata-rata & & & 8,52 \\
\hline
\end{tabular}

Berdasarkan tabel 4.4. pada aspek menulis paragraf argumentasi “ mengembangkan kerangka" dari 36 siswa terdapat 4 siswa yang mencapai kategori sangat baik dengan interval skor 12 15 , atau sebesar $11,1 \%$. Untuk kategori baik dengan interval skor 8-11 dicapai oleh 14 siswa atau sebesar $38,9 \%$. Untuk yang berkategori cukup dengan interval skor 4-7 dicapai oleh 17 siswa atau sebesar 47,2\%. Sedangkan untuk kategori kurang dengan interval 0-3 dicapai oleh 1 siswa atau $2,8 \%$. 
Berdasarkan nilai rata-rata siswa yang diperoleh sebesar 8,52. Hasil tersebut termasuk dalam kategori cukup, artinya keterampilan siswa dalam penguasaan aspek "mengembangkan kerangka" termasuk dalam kategori cukup. Pada aspek "mengembangkan kerangka" dalam siklus I ini , masih banyak siswa yang belum dapat mengembangkan kerangka dengan lengkap. Pada aspek ini sebagian besar siswa, banyak yang mendapat nilai berkategori cukup dengan interval skor 4-7. Ini berarti banyak siswa mengembangkan kerangka tidak lengkap.

Tabel 4.5. Daftar Penilaian Aspek "Menyunting paragraf"

\begin{tabular}{lllcc}
\hline No. & Kategori & Interval & \multicolumn{2}{c}{ Frekuens } \\
i & \% \\
\hline & & Skor & & \\
\hline 1. & Sangat baik & $21-30$ & 2 & 5,6 \\
\hline 2. & Baik & $16-20$ & 8 & 22,2 \\
\hline 3. & Cukup & $11-15$ & 12 & 33,3 \\
\hline 4. & Kurang & $0-10$ & 14 & 38,9 \\
\hline Jumlah & & 36 & 100 \\
\hline Rata-rata & & & 14,7 \\
\hline
\end{tabular}

Berdasarkan tabel 4.5. pada aspek menulis paragraf argumentasi “ menyunting paragraf" dari 36 siswa terdapat 2 siswa yang mencapai kategori sangat baik dengan interval skor 21-30, atau sebesar $5,6 \%$. Untuk kategori baik dengan interval skor 16-201 dicapai oleh 8 siswa atau sebesar $22,2 \%$. Untuk yang berkategori cukup dengan interval skor 11-15 dicapai oleh 12 siswa atau sebesar $33,3 \%$. Sedangkan untuk kategori kurang dengan interval 0-10 dicapai oleh 14 siswa atau $38,9 \%$.

Berdasarkan nilai rata-rata siswa yang diperoleh sebesar 14,7. Hasil tersebut termasuk dalam kategori kurang, artinya keterampilan siswa dalam penguasaan aspek "menyunting paragraf" termasuk dalam kategori kurang. Pada aspek "menyunting paragraf" dalam siklus I ini, masih banyak siswa dalam penulisan kata yang disunting tidak sesuai dengan pilihan kata. Pada aspek ini sebagian besar siswa, banyak yang mendapat nilai berkategori kurang dengan interval skor 0-10. Ini berarti banyak siswa dalam penulisan kata yang disunting tidak sesuai dengan pilihan kata.

Tabel 4.7. Deskripsi Ketuntasan hasil tes siklus I kelas X.1 Madrasah Aliyah Negeri 1 Makassar

\begin{tabular}{|c|c|c|c|}
\hline Kriteria & Kategori & Frekuensi & Persen \\
\hline \multicolumn{4}{|l|}{ Ketuntasan } \\
\hline-64 & Tidak tuntas & 28 & $77,8 \%$ \\
\hline-100 & Tuntas & 8 & $22,2 \%$ \\
\hline \multicolumn{2}{|c|}{ Jumlah } & 36 & 100 \\
\hline
\end{tabular}


Berdasarkan tabel di atas dapat dilihat bahwa persentase ketuntasan menulis paragraf argumentasi dengan menggunakan metode pembelajaran Scaffolding Metakognisi sebesar 22,2\% atau 8 orang siswa dari 36 orang siswa termasuk dalam kategori tuntas, dan $77,8 \%$ atau 28 orang murid dari 36 orang siswa termasuk dalam kategori tidak tuntas. Hal tersebut menunjukkan bahwa masih terdapat 28 siswa perlu perbaikan karena belum mencapai kriteria ketuntasan minimum yang ditetapkan.

Berdasarkan data hasil tes/evaluasi, observasi yang telah dilaksanakan pada pelaksanaan tindakan siklus I belum mencapai target indikator keberhasilan yang ditetapkan. Denga kata lain masih ada kekurangan atau kelemahankelemahan yang terjadi. Adapun kelemahan yang terjadi pada siklus I ialah:

a) Peneliti belum terbiasa menciptakan Susana pembelajaran yang menggunakan metode pembelajaran Scaffolding Metakognisi

b) Sebagian siswa belum terbiasa dengan kondidsi belajar dengan menggunkan metode pembelajaran Scaffolding Metakognisi

c) Masih ada siswa yang memiliki kemampuan menulis topik, menyusun kerangka, mengembangkan kerangka dan menyunting paragraf argumentasi berkategori rendah pada siklus pertama

Maka pada pelaksanaan siklus kedua dibuat perencanaan sebagai berikut:

1. Memberikan motivasi kepada siswa agar lebih aktif lagi dalam pembejaran dengan penerapan metode pembelajaran Scaffolding Metakognisi

2. Lebih intensif membimbing siswa yang mengalami kesulitan

3. Memberi pengakuan atau penghargaan (reword)

\section{Kegiatan Hasil Siklus II}

Seperti pada siklus pertama, siklus kedua ini terdiri dari empat tahapan yakni perencanaan, pelaksanaan, observasi dan refleksi

Pada siklus kedua, penggunaan metode Scaffolding Metakognisi yang diterapkan mengalami peningkatan dimana siswa mulai beradaptasi dan kerjasama sudah mulai terorganisir dengan baik sehingga siswa termotivasi untuk belajar. Adapun hasil observasi untuk mengetahui perubahan sikap siswa selama siklus II dapat dilihat pada tabel berikut:

Table 4.8. Data hasil Observasi sikap Siswa selama mengikuti pembelajaran siklus II

\begin{tabular}{|c|c|c|c|c|c|c|c|}
\hline \multirow{2}{*}{ No } & \multirow{2}{*}{ Komponen yang diamati } & \multicolumn{4}{|c|}{ Pertemuan ke- } & \multirow{2}{*}{$\begin{array}{c}\text { Rata- } \\
\text { rata }\end{array}$} & \multirow{2}{*}{$\begin{array}{r}\text { Persenta } \\
\text { s e }(\%) \\
\end{array}$} \\
\hline & & $\bar{I}$ & II & III & IV & & \\
\hline 1 & $\begin{array}{l}\text { Jumlah siswa yang hadir pada saat } \\
\text { kegiatan pembelajaran }\end{array}$ & 35 & 36 & 36 & 36 & 35,75 & 99,30 \\
\hline 2 & $\begin{array}{l}\text { Siswa yang memperhatikan pada } \\
\text { saat proses pembelajaran }\end{array}$ & 30 & 30 & 32 & 36 & 32 & 88,88 \\
\hline 3 & $\begin{array}{l}\text { Siswa yang melakukan aktifitas } \\
\text { negative selama proses } \\
\text { pembelajaran (main-main, rebut } \\
\text { dan lain-lain) }\end{array}$ & 1 & 1 & 0 & 0 & 0,5 & 1,3 \\
\hline
\end{tabular}




\begin{tabular}{|c|c|c|c|c|c|c|c|}
\hline 4 & $\begin{array}{l}\text { Siswa yang aktif dalam } \\
\text { pembelajaran }\end{array}$ & 27 & 29 & 31 & 30 & 29,25 & 81,25 \\
\hline 5 & $\begin{array}{l}\text { Siswa yang memahami materi } \\
\text { yang diajarkan }\end{array}$ & 27 & 29 & 30 & 29 & 28,75 & 79,86 \\
\hline 6 & $\begin{array}{l}\text { Siswa yang masih perlu bimbingan } \\
\text { guru pada saat mengerjakan soal }\end{array}$ & 4 & 2 & 2 & 1 & 2,25 & 6,2 \\
\hline 7 & $\begin{array}{l}\text { Siswa yang kurang memahami } \\
\text { materi }\end{array}$ & 5 & 2 & 2 & 1 & 2,5 & 6,94 \\
\hline 8 & $\begin{array}{l}\text { Siswa yang bertanya tentang } \\
\text { materi yang belum dimengerti }\end{array}$ & 3 & 2 & 2 & 1 & 2 & 5,56 \\
\hline
\end{tabular}

Berdasarkan tabel 4.8. diperoleh bahwa pada siklus II dari 36 siswa, yang hadir pada saat kegiatan pembelajaran sebanyak $99,3 \%$ siswa yang memperhatikan pada saat proses pembelajaran sebanyak $88,88 \%$, siswa yang melakukan aktifitas negative selama proses pembelajaran (main-main, rebut, dan lain-lain) mencapai 1,3\%, siswa yang aktif dalam pembelajaran $81,25 \%$, siswa yang memahami materi $79,86 \%$, siswa yang masih perlu bimbingan guru pada saat mengerjakan soal sebanyak $6,2 \%$, siswa yang kurang memahami materi sebanyak 6,94\%, dan siswa yang bertanya tentang materi yang diajarkan sebanyak $5,56 \%$. Sealnjutnya untuk

mengetahui peningkatan data kemampuan menulis paragraf argumentasi siswa dapat dilihat pada tabel tes siklus II sebagai berikut :

\section{1) Penilaian Aspek Peningkatan, Menulis Topik, Menyusun Kerangka, Mengembangka Kerangka, dan Menyunting Paragraf Siklus II.}

Untuk soal peningkatan menulis paragraf argumentasi mengacu pada indikator mampu menulis topik, menyusun kerangka, mengembangkan kerangka, dan menyunting paragraf.

Tabel 4.9. Daftar Penilaian Aspek "Menulis Topik"

\begin{tabular}{lllcc}
\hline No. & Kategori & $\begin{array}{l}\text { Interval } \\
\text { Skor }\end{array}$ & Frekuensi & \% \\
\hline 1. & Sangat baik & $12-15$ & 17 & 52,8 \\
\hline 2. & Baik & $8-11$ & 19 & 47,2 \\
\hline $3 . \quad$ Cukup & $4-7$ & 0 & 0 \\
\hline $4 . \quad$ Kurang & $0-3$ & 0 & 0 \\
\hline Jumlah & & 36 & 100 \\
\hline \multicolumn{2}{l}{ Rata-rata } & & 12,3 \\
\hline
\end{tabular}

Berdasarkan tabel 4.9. pada aspek menulis paragraf argumentasi " menulis topik " dari 36 siswa terdapat 17 siswa yang mencapai kategori sangat baik dengan interval skor 12-15, atau sebesar
52,8\%.Untuk kategori baik dengan interval skor 8-11 dicapai oleh 19 siswa atau sebesar 47,2\%. Untuk yang berkategori cukup dan kurang tidak terdapat siswa. 
Siswa rata-rata sudah dapat menuliskan topik sesuai dengan paragraf, namun masih ada yang menuliskan topik kurang sesuai dengan paragraf . Dari 36 siswa yang diteliti, 17 siswa menulis topik yang sesuai dengan paragraf. Nilai rata-rata yag diperoleh siswa sebesar 12,3 berkategori baik. Pada aspek ini sebagian besar siswa, banyak yang mendapat nilai berkategori baik dengan interval skor 811. Sehingga, dapat disimpulkan bahwa penilaian aspek "menulis topik" pada siklus II ini meningkat.

Tabel 4.10. Daftar Penilaian Aspek "Menyusun Kerangka"

\begin{tabular}{lllcc}
\hline No. & Kategori & $\begin{array}{l}\text { Interval } \\
\text { Skor }\end{array}$ & Frekuensi & $\%$ \\
\hline 1. & Sangat baik & $12-15$ & 16 & 44,4 \\
\hline 2. & Baik & $8-11$ & 20 & 55.6 \\
\hline 3. & Cukup & $4-7$ & 0 & 0 \\
\hline $4 . \quad$ Kurang & $0-3$ & 0 & 0 \\
\hline Jumlah & & 36 & 100 \\
\hline Rata-rata & & & 12,1 \\
\hline
\end{tabular}

Berdasarkan tabel 4.10. pada aspek menulis paragraf argumentasi " menyusun kerangka " dari 36 siswa terdapat 16 siswa yang mencapai kategori sangat baik dengan interval skor $12-15$, atau sebesar $44,4 \%$. Untuk kategori baik dengan interval skor 8-11 dicapai oleh 20 siswa atau sebesar $55.6 \%$. dan tidak ada siswa pada kategori cukup dan kurang.

Siswa rata-rata sudah dapat menyusun kerangka dengan lengkap, namun masih ada yang menyusun kerangka masih kurang lengkap . Dari 36 siswa yang diteliti, 16 siswa menyusun kerangka sudah lengkap. Nilai rata-rata yag diperoleh siswa sebesar 12,1 berkategori baik. Pada aspek ini sebagian besar siswa, banyak yang mendapat nilai berkategori baik dengan interval skor 8-11. Sehingga, dapat disimpulkan bahwa penilaian aspek "menyusun kerangka" pada siklus II ini meningkat.

Tabel 4.11. Daftar Penilaian Aspek "Mengembangkan Kerangka"

\begin{tabular}{lllcc}
\hline No. & Kategori & $\begin{array}{l}\text { Interval } \\
\text { Skor }\end{array}$ & Frekuensi & \% \\
\hline 1. & Sangat baik & $12-15$ & 17 & 47,2 \\
\hline 2. & Baik & $8-11$ & 19 & 52,8 \\
\hline 3. & Cukup & $4-7$ & 0 & 16,7 \\
\hline 4. & Kurang & $0-3$ & 0 & 2,8 \\
\hline Jumlah & & 36 & 100 \\
\hline
\end{tabular}


Berdasarkan tabel 4.11. pada aspek menulis paragraf argumentasi “ mengembangkan kerangka" dari 36 siswa terdapat 17 siswa yang mencapai kategori sangat baik dengan interval skor 12-15, atau sebesar 47,2\%. Untuk kategori baik dengan interval skor 8-11 dicapai oleh 19 siswa atau sebesar $52,8 \%$. Dan tidak ada pada kategori cukup dan kurang.

Siswa rata-rata sudah dapat mengembangkan kerangka dengan lengkap, namun masih ada yang menyusun kerangka masih kurang lengkap . Dari 36 siswa yang diteliti, 17 siswa menyusun kerangka sudah lengkap. Nilai rata-rata yag diperoleh siswa sebesar 12,5 berkategori baik. Pada aspek ini sebagian besar siswa, banyak yang mendapat nilai berkategori baik dengan interval skor 8-11.

Sehingga, dapat disimpulkan bahwa penilaian aspek "mengembangkan kerangka" pada siklus II ini meningkat.

Tabel 4.12. Daftar Penilaian Aspek "Menyunting paragraf"

\begin{tabular}{lllcc}
\hline No. & Kategori & $\begin{array}{l}\text { Interval } \\
\text { Skor }\end{array}$ & Frekuensi & \% \\
\hline 1. & Sangat baik & $21-30$ & 8 & 22,2 \\
\hline 2. & Baik & $16-20$ & 25 & 69,5 \\
\hline 3. & Cukup & $11-15$ & 3 & 8,3 \\
\hline 4. & Kurang & $0-10$ & 0 & 0 \\
\hline Jumlah & & 36 & 100 \\
\hline
\end{tabular}

Rata-rata

Berdasarkan tabel 4.12. pada aspek menulis paragraf argumentasi " menyunting paragraf" dari 36 siswa terdapat 8 siswa yang mencapai kategori sangat baik dengan interval skor 21-30, atau sebesar $22.2 \%$. Untuk kategori baik dengan interval skor 16-201 dicapai oleh 25 siswa atau sebesar $69,5 \%$. Untuk yang berkategori cukup dengan interval skor 11-15 dicapai oleh 3 siswa atau sebesar $8,3 \%$. Sedangkan tidak ada pada kategori kurang.

Siswa rata-rata sudah dapat menyunting kesalahan sesuai dengan pilihan kata, namun masih ada yang menyunting kesalahan tidak sesuai dengan pilihan kata . Dari 36 siswa yang diteliti, 8 siswa menyunting kesalahan sesuai dengan pilihan kata. Nilai rata-rata yag diperoleh siswa sebesar 20 berkategori baik.. Sehingga, dapat disimpulkan bahwa penilaian aspek "menyunting paragraf " pada siklus II ini meningkat.

2) Penilaian Hasil Keseluruhan Menulis Paragraf Argumentasi Siklus II 
Tabel 4.13 : Distribusi Frekuensi dan Persentase Hasil Tes Siklus II

\begin{tabular}{ccccc}
\hline NO & Skor & Kategori & Frekuensi & Persentase \\
\hline $\mathbf{1 .}$ & $0-34$ & Sangat rendah & 0 & 0 \\
\hline $\mathbf{2 .}$ & $35-54$ & Rendah & 1 & 2,8 \\
\hline $\mathbf{3 .}$ & $55-64$ & Sedang & 2 & 5,5 \\
\hline $\mathbf{4 .}$ & $65-84$ & Tinggi & 23 & 63,9 \\
\hline $\mathbf{5 .}$ & $85-100$ & Sangat tinggi & 10 & 27,8 \\
\hline & Jumlah & & $\mathbf{3 6}$ & $\mathbf{1 0 0}$ \\
\hline
\end{tabular}

Berdasarkan hasil evaluasi yang diberikan pelaksanaan tindakan siklus II lebih baik dibanding dengan tes siklus I. Pada tabel XIII di atas dapat di kemukakan bahwa 36 siswa Kelas X.1 Madrasah Aliyah Negeri 1 Makassar tidak ada siswa yang berada pada kategori sangat rendah, pada kategori rendah terdapat 1 siswa atau sekitar $2,8 \%$ kemudian, pada kategori sedang terdapat 2 siswa atau sekitar 5,5\% pada kategori tinggi terdapat 23 siswa atau sekitar $63,9 \%$, dan pada kategori sangat tinggi terdapat 10 siswa atau sekitar 27,8. Dapat dilihat perbedaan pada perbandingan siklus I dan siklus II sehingga dapat disimpulkan bahwa penerapan metode Scaffolding
Metakognisi telah meningkatkan kemampuan menulis paragraf argumentasi siswa pada mata pelajaran bahasa Indonesia Kelas X.1 Madrasah Aliyah Negeri 1 Makassar dan ini merupakan sebuah keberhasilan dari proses balajar mengajar.

Apabila hasil tes kemampuan menulis paragraf argumentasi siswa Kelas X.1 Madrasah Aliyah Negeri 1 Makassar pada siklus II dikategorikan dalam kriteria ketuntasan minimum yang berlaku di Kelas $X_{{ }_{1}}$ Madrasah Aliyah Negeri 1 Makassar untuk mata pelajaran bahasa Indonesia dapat dilihat pada tabel 4.14. berikut:

Tabel 4.14. Deskripsi Ketuntasan hasil tes siklus II kelas X.1 Madrasah

\begin{tabular}{|c|c|c|c|}
\hline \multicolumn{3}{|c|}{ Aliyah Negeri 1 Makassar } & \multirow[b]{2}{*}{ Persen } \\
\hline Kriteria & Kategori & Frekuensi & \\
\hline \multicolumn{4}{|l|}{ Ketuntasan } \\
\hline $0-64$ & Tidak tuntas & 3 & $8,3 \%$ \\
\hline $65-100$ & Tuntas & 33 & $91,7 \%$ \\
\hline \multicolumn{2}{|c|}{ Jumlah } & 36 & 100 \\
\hline
\end{tabular}

Berdasarkan tabel diatas dapat dilihat bahwa persentase ketuntasan menulis paragraf argumentasi dengan menggunakan metode pembelajaran Scaffolding Metakognisi 33 siswa dalam kategori tuntas dan 3 siswa yang masuk dalam kategori tidak tuntas.
Adapun keberhasilan yang diperoleh selama kedua ini adalah:

a. Aktivitas siswa dalam proses belajar mengajar sedah mengarah pada konsep pembelajaran yang peneliti terapkan.

b. Meningkatkan aktivitas siswa dalam proses belajar mengajar 
didukung oleh meningkatnya aktivitas peneliti dan guru dalam mempertahankan dan meningkatkan Susana pembelajaran yang mengarah pada pembelajaran metode Scaffolding Metakognisi. Peneliti intensif membimbing saat siswa mengalami kesulitan dan ini dapat dilihat dari hasil observasi dan evaluasi siswa mengalami peningkatan.

Pada siklus ke dua ini peneliti memberikan angket untuk mengetahui tanggapan siswa terhadap penerapan metode Scaffolding Metakognisi.

\section{Hal-hal lain yang ditemukan selama Proses Pembelajaran}

Disamping adanya peningkatan penguasaan materi paragraf argumentasi dalam proses belajar mengajar dengan penerapan metode pembelajaran Scaffolding Metakognisi, juga ditemukan hal-hal lain diantaranya: 1. Semangat/antusias

Dari pengamatan yang dilakukan peneliti selama dua siklus pengajaran melalui proses belajar mengajar dengan penerapan metode pembelajaran Scaffolding Metakognisi, terlihat adanya peningkatan hasil belajar juga adanya semangat siswa dalam mengikuti proses belaar mengajar dengan penerapan metode pembelajaran Scaffolding Metakognisi. Hal ini dapat dilihat dari peningkatan jumlah siswa yang aktif pada saat proses belajar berlangsung.

2. Motivasi dan Minat

Selama penelitian dilaksanakan motivasi dan minat belajar siswa terhadap pelajaran bahasa Indonesia khususnya menulis paragraf argumentasi semakin meningkat, hal ini dilihat semakin kurangnya siswa melakukan kegiatan lain selama pembahasan materi berlangsung.

3. Percaya diri
Demikian juga halnya dengan rasa percaya diri siswa meningkat selama mengikuti dua siklus dalam proses belajar mengajar. Pada umumnya siswa mempunyai pendapat bahwa mereka tidak yakin dapat menyelesaikan tugastugas dan memperoleh hasil yang maksimal. Akan tetapi dengan adanya dorongan dan motivasi selama pelaksanaan tindakan pandangan siswa yang sedemikian berkurang. Hal ini bisa terlihat dari jawaban-jawaban soal yang dberikan, dan tanya jawab. Hal ini terjadi karena adanya peningkatan percaya diri siswa.

\section{B. Pembahaasan}

Pada siklus I kegiatan pembelajaran berlangsung, siswa yang sebelumnya kurang semangat dalam mengikuti proses pemebelajaran menulis paragraf argumenetasi. Hal ini disebabkan dengan metode yang diterapkan oleh guru kurang tepat karena metode sangat berpengaruh dalam proses pembelajaran.

Setelah diadakan refleksi kegiatan pada siklus I, maka dilakukan beberapa perbaikan kegiatan yang dianggap perlu yakni lebih memotivasi siswa pada saat mengikuti proses pembelajaran, hal ini dilakukan untuk membangkitkan semangat belajar siswa Kelas $\mathrm{X}_{._{1}}$ Madrasah Aliyah Negeri 1 Makassar, selain itu guru harus lebih tegas dalam mengatur siswa yang tidak memperhatikan penjelasan materi karena akan berpengaruh dengan hasil belajar.

Pada siklus II, terlihat bahwa peningkatan kemampuan menulis paragraf argumentasi Kelas X. ${ }_{1}$ Madrasah Aliyah Negeri 1 Makassar mengalami peningkatan dari siklus I ke siklus II. Hal tersebut menunjukkan bahwa jumlah siswa yang berada pada kategori tuntas mengalami peningkatan yakni 7 orang atau $19,45 \%$ pada siklus I, kemudian naik menjadi 32 orang atau $88,89 \%$ pada 
siklus II. Untuk melihat peningkatan kemampuan menulis paragraf argumentasi mealalui aspek penilaian "menulis topik, menyusun kerangka, mengembangkan kerangka dan meyunting paragraf" melalui metode Scaffolding Metakognisi Kelas $\mathrm{X}_{1}$ Madrasah Aliyah Negeri 1 Makassar berdasarkan hasil tes untuk setiap siklus akan disajikan sebagai berikut

Tabel 4. 16 Gambaran Hasil Peningkatan Kemampuan Menulis Paragraf Argumentasi Pada Aspek "Menulis Topik, Menyusun Kerangka, Mengembangkan Kerangka, Menyunting Paragraf"

\begin{tabular}{|c|c|c|c|c|c|c|c|c|c|}
\hline \multirow{2}{*}{$\begin{array}{c}\text { Hasil } \\
\text { Tes }\end{array}$} & \multirow{2}{*}{$\begin{array}{c}\text { ASPEK } \\
\text { PENILAIA } \\
\text { N }\end{array}$} & \multirow[t]{2}{*}{$\mathbf{N}$} & \multicolumn{2}{|c|}{ Ketuntasan } & \multicolumn{5}{|c|}{ Skor } \\
\hline & & & $\begin{array}{l}\text { Tun } \\
\text { tas }\end{array}$ & $\begin{array}{c}\text { Tidak } \\
\text { Tuntas }\end{array}$ & $\begin{array}{c}\text { Idea } \\
1\end{array}$ & $\begin{array}{l}\text { Terti } \\
\text { nggi }\end{array}$ & $\begin{array}{l}\text { Tere } \\
\text { nda } \\
\text { h }\end{array}$ & $\begin{array}{l}\text { Rata- } \\
\text { rata }\end{array}$ & $\%$ \\
\hline \multirow[t]{5}{*}{$\begin{array}{l}\text { SIKL } \\
\text { US I }\end{array}$} & $\begin{array}{l}\text { Menulis } \\
\text { topik }\end{array}$ & 36 & 17 & 19 & 15 & 15 & 3 & 8,28 & \multirow{5}{*}{22,2} \\
\hline & $\begin{array}{c}\text { Menyusun } \\
\text { kerangka }\end{array}$ & 36 & 16 & 20 & 15 & 15 & 3 & 8,50 & \\
\hline & $\begin{array}{c}\text { Mengemban } \\
\text { gkan } \\
\text { kerangka }\end{array}$ & 36 & 18 & 18 & 15 & 15 & 3 & 8,52 & \\
\hline & $\begin{array}{l}\text { Menyunting } \\
\text { paragarf }\end{array}$ & 36 & 10 & 26 & 30 & 25 & 9 & 14,7 & \\
\hline & Hasil & 36 & 8 & 28 & 100 & 80 & 36 & 53,3 & \\
\hline \multirow[t]{4}{*}{$\begin{array}{l}\text { SIKL } \\
\text { US II }\end{array}$} & $\begin{array}{c}\text { Menulis } \\
\text { topik }\end{array}$ & 36 & 36 & 0 & 15 & 15 & 8 & 12,3 & \multirow{4}{*}{91,7} \\
\hline & $\begin{array}{l}\text { Menyusun } \\
\text { kerangka }\end{array}$ & 36 & 36 & 0 & 15 & 15 & 8 & 12,1 & \\
\hline & $\begin{array}{c}\text { Mengemban } \\
\text { gkan } \\
\text { kerangka }\end{array}$ & 36 & 36 & 0 & 15 & 15 & 8 & 12,5 & \\
\hline & $\begin{array}{l}\text { Menyunting } \\
\text { paragarf }\end{array}$ & 36 & 33 & 3 & 30 & 25 & 13 & 20 & \\
\hline
\end{tabular}




\section{$\begin{array}{llllllll}\text { Hasil } & 36 & 36 & 0 & 100 & 96 & 57 & 76\end{array}$}

Berdasarkan tabel diatas dapat dilihat bahwa nilai rata-rata hasil tes kemampuan menulis paragraf argumentasi dalam aspek penilaian "menulis topik, menyusun kerangka, mengembangkan kerangka, menyunting paragraf" siswa kelas Kelas $\mathrm{X}_{1}$ Madrasah Aliyah Negeri 1 Makassar yang dilaksanakan dalam dua siklus mengalami peningkatan pada akhir siklus I nilai rata-rata yang diperoleh siswa pada aspek "menulis topik" adalah 8,28 dan berada pada kategori cukup,pada aspek "menyusun kerangka" adalah 8,50 kategori cukup, pada aspek "mengembangkan kerangka" adalah 8,52 kategori cukup, pada aspek "menyunting paragraf " adalah 14,7 kategori cukup sedangkan pada hasil keseluruhan adalah 53,3 pada kategori cukup. Sedangkan akhir siklus II nilai rata-rata yang diperoleh siswa pada aspek "menulis topik" adalah 12,3 dan berada pada kategori tinggi, pada aspek "menyusun kerangka" adalah 12,1 kategori tinggi, pada aspek "mengembangkan kerangka" adalah 12,5 kategori tinggi, pada aspek "menyunting paragraf " adalah 18,9 kategori tinggi sedangkan pada hasil keseluruhan adalah 76 pada kategori tinggi. Dari hasil ini menunjukkan adanya peningkatan nilai rata-rata hasil tes kemampuan menulis paragraf argumentasi siswa kelas Kelas $\mathrm{X}_{1}$ Madrasah Aliyah Negeri 1 Makassar melalui penerapan metode pembelajaran Scaffolding Metakognisi dari 22,2 \% menjadi 91,7 \%. Namun, dari hasil penelitian siklus II masih ada 3 orang yang tidak tuntas sehingga dalam penerapan metode Scaffolding Metakognisi harus dilakukan lebih intensif.
Kesimpulan dari proses pembelajaran siklus II adalah hasil belajar siswa pada pelajaran bahasa Indonesia secara klasikal telah mencapai standar ketuntasan belajar.

\section{KESIMPULAN}

Berdasarkan hasil pembahasan penelitian yang disajikan dalam bab IV yaitu penelitian tindakan kelas yang dilaksanakan pada siswa Kelas $\mathrm{X}_{\cdot 1}$ Madrasah Aliyah Negeri 1 Makassar tahun pelajaran 2015-2016 dapat disimpulkan sebagai berikut:

Penerapan, metode pembelajaran Scafoollding Metakognisi dapat meningkatkan kemampuan menulis paragraf argumentasi pada aspek "menulis topik,menyusun keramgka, mengembangkan kerangka, menyunting paragraf". Hal ini ditunjukkan dari hasil nilai rata-rata keseluruhan dan nilai tes akhir yang mengalami peningkatan. Hal ini tampak dari pencapaian rata-rata hasil tes siklus I 22,2 meningkat menjadi 74,3 pada siklus ke II .

\section{DAFTAR PUSTAKA}

Akhadiah, Sabarti, dkk. 1998. Pembinaan Keterampilan Menulis Bahasa Indonesia. Jakarta: Erlangga.

Aminuddin. 2001. Problematika Bahasa dan Pengajarannya. Surabaya: Usaha Nasional.

Arikunto, Suharsimi. 1998. Prosedur Penelitian, Suatu Pendekatan Praktik. Jakarta: Rineka Cipta. 
Confrey, Jere. 1990. What Consructivism Implies for Teaching. JRM. E Constructivist Views on Teaching ang Learning. Page 107122 .

Flavell. 1976. Metakognisi. (Online), Jilid 3, No. 12, htpp://www.google.com, diakses pada tanggal 3 Januari 2012.

Hidayat, Rahayu S. 1990. Pengetesan Kemampuan Membaca Secara

Komunikatif. Jakarta: Intermasa.

Kosasih, E. 2012. Dasar - Dasar

Keterampilan Menulis. Bandung: Yrama Widya

Munirah. 2007. Dasar Keterampilan Menulis. Diktat. Makassar: Unismuh

Nur, Muhammad. 2000.

Strategi-strategi

Belajar. Surabaya:

Pusat Studi

Matematika, dan IPA

Sekolah, Unesa

Nurgiyantoro, Burhan. 2001. Penilaian

dalam Pembelajaran Bahasa dan Sastra.

Yogyakarta: BPFE.

O’Neil JR Brown. 1997. Differential Effects of Question Formats in Math Assessement on Metacognition and Affect. Los Angeles:

CRESST-CSE University of California.

Rahim, Abd. Rahman. 2002. Pembinaan dan Pengembangan Bahasa Indonesia. Diktat. Makassar: Unismuh.

Syafi'ie Imam. 2001. Terampil Berbahas Indonesia. Jakarta: Depdikbud.
Tarigan, Henri Guntur. 1992. Strategi pembelajaran Bahasa. Bandung:

Angkasa.

Unismuh, FKIP, 2012. Pedoman

Penulisan Skripsi. Makassar.

Vygotsky. 1846. Scaffolding. (Online), Jilid 7 , No.20, http://www.google.com. Diakses pada tanggal 3 Januari 2012.

Wijaya, Kusumah. 2011.

Mengenal Penelitian

Tindakan Kelas. Jakarta:

PT

Indeks. 